Zukow Walery, Flyunt Igor-Severyn S., Ponomarenko Ruslan B., Rybak Nadiya Y., Fil' Vitaliy M., Kovalchuk Halyna Y., Sarancha Serhiy M., Nahurna Yaryna V. Polivariant change of step-test under the influence of natural adaptogens and their accompaniments. Pedagogy and Psychology of Sport. 2020;6(2):74-84. elSSN 2450-6605. DOI http://dx.doi.org/10.12775/PPS.2020.06.02.007 https://apcz.umk.pl/czasopisma/index.php/PPS/article/view/PPS.2020.06.02.007 https://zenodo.org/record/3767282

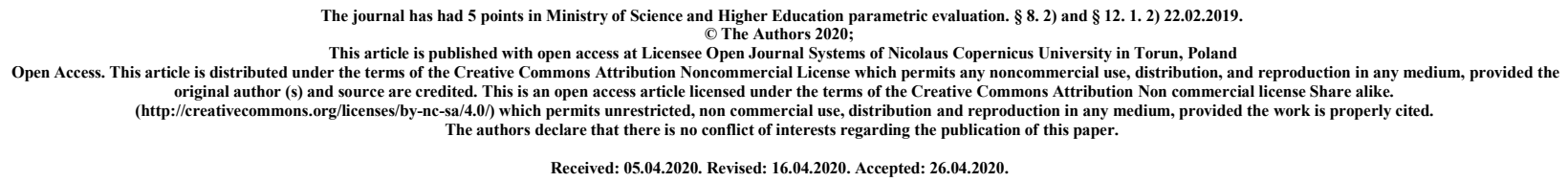

\title{
Polivariant change of step-test under the influence of natural adaptogens and their accompaniments
}

\author{
Walery Zukow ${ }^{1}$, Igor-Severyn S. Flyunt ${ }^{2}$, Ruslan B. Ponomarenko ${ }^{3}$, Nadiya Y. Rybak ${ }^{3}$, \\ Vitaliy M. Fil'2, Halyna Y. Kovalchuk ${ }^{2}$, Serhiy M. Sarancha ${ }^{4}$, Yaryna V. Nahurna ${ }^{5}$ \\ ${ }^{1}$ Nicolaus Copernicus University, Torun, Poland w.zukow@wp.pl \\ ${ }^{2}$ Ivan Franko Pedagogical University, Drohobych, Ukraine fillvitalij@gmail.com \\ ${ }^{3}$ Communal Hospital, Truskavets', Ukraine karapuzia@ukr.net \\ ${ }^{4}$ Children's Sanatorium "Dzherelo", Truskavets', Ukraine \\ ${ }^{5}$ Danylo Halyts'ky̌̌ National Medical University, L'viv, Ukraine
}

Corresponding Author Walery Zukow, E-mail: w.zukow@wp.pl

\begin{abstract}
Background. Typically, the step test is used to assess the physical performance that is determined by the condition of the cardio-respiratory system. The latter, in turn, is associated with the nervous, endocrine and immune systems, which collectively determine the level of adaptation of the body. The purpose of this study is to analyze the effect on the step test of natural adaptogens and associated changes in a number of parameters of cardio-respiratory, autonomic nervous and immune systems and metabolism. Material and methods. The target was 80 children of both sexes, ages 10-17, arriving at the clinical sanatorium "Dzherelo" of Truskavets spa from radionuclide contaminated territories. The main subject of the study was the Popovych's step test. State of autonomous nervous and immune systems was assessed as well as
\end{abstract}


others functional and metabolic tests. Results. The contingent surveyed was retrospectively divided into three qualitatively distinct groups. The largest group $(53,7 \%)$ was the group of children with initially reduced or normal levels of Popovych's Step Test Index (PSI), in which it increased. However, in $28,8 \%$ of children PSI remained stable at different initial levels, and in $17,5 \%$ even decreased, without falling below the lower limit of normal. Discriminant analysis

was subsequently applied to identify constellations of parameters that change are characteristic of each cluster. The program selected as characteristic changes in 2 parameters of autonomous nervous system, 2 functional, 4 metabolic and 3 immune parameters as well as blood trombocytes level. The correct classification of the positive actotropic effect is 93,0\%; neutral 65,2\%; negative $64,3 \%$, and total correctness is $80,0 \%$. Conclusion. Balneotherapy causes multivariate changes in Popopvych's step test, which accompanied by characteristic changes in certain parameters of autonomous nervous and immune systems as well as others functional and metabolic tests.

Key words: Step test, HRV, Immunity, Metabolism, Balneotherapy, Children.

\section{INTRODUCTION}

Assessment of the functional state of the cardiovascular system, which limits the level of physical performance, is impossible without the use of load tests. The results of functional tests depend not only on the state of the heart and blood vessels, but also on the state of neuroregulatory mechanisms. Increasing the rhythm frequency during muscular work is mainly due to increased sympathetic effects on the heart and, to some extent, decreased parasympathetic $[1,6,7]$. The condition of the cardio-respiratory system is associated with the nervous, endocrine and immune systems, which collectively determine the level of adaptation of the body $[9,11,16,17]$. The purpose of this study is to analyze the effect on the step test of natural adaptogens and associated changes in a number of parameters of cardio-respiratory, autonomic nervous and immune systems and metabolism.

\section{MATERIAL AND METHODS}

The target was 80 children of both sexes, ages 10-17, arriving at the clinical sanatorium "Dzherelo" of Truskavets spa from radionuclide contaminated territories (density ${ }^{137} \mathrm{Cs} 37 \div 93$ $\mathrm{kBq} / \mathrm{m}^{2}$ ). According to $\gamma$-spectrometry performed with a human radiation meter "Screensaver$3 \mathrm{M} "$, the activity of incorporated ${ }^{137} \mathrm{Cs}$ was $1,5 \div 35 \mathrm{~Bq} / \mathrm{kg}$.

The main subject of the study was the step test. As early as 1982, Dushanin SA et al [7] offered a modification of the step test to quantify the level of physical performance. The essence of the test is to rhythmically climb the stairs (height $37 \mathrm{~cm}$ ) and lower it 90 times within 3 minutes. Both the pulse response to the load (whose power is $2,412 \mathrm{~W} / \mathrm{kg}$ ) and the speed of recovery are taken into account. The authors propose to calculate the index of physical performance (IPP) by the formula:

$\mathrm{IPP}=(\mathrm{P} 1+\mathrm{P} 2+\mathrm{P} 3-200) / 10$, where

$\mathrm{P} 1$ is pulse (heart rate) for $1 \mathrm{~min}$ in position sitting after $5 \mathrm{~min}$ of rest;

$\mathrm{P} 2$ is heart rate for the first $10 \mathrm{sec}$ after loading, multiplied by 6;

P3 is heart rate for the first $10 \mathrm{sec}$ of the second minute of recovery, multiplied by 6 . 
However, this formula does not take into account the actual time (t) spent by 90 ascents, so Popovych IL [28] has proposed a variant of the step test index (PSTI):

$\mathrm{PSTI}=180 \bullet 100 /\left(\mathrm{HR}_{1}+\mathrm{HR}_{2}+\mathrm{HR}_{3}-200\right) \bullet \mathrm{t}$

State of autonomous nervous system was assessed by the method of HRV [2] using the "Cardio" device (Kyiv). However, on the basis of indicators of heart rate sitting and standing calculated Teslenko's index [6]. In the same vein, an Anfimov's corrective test was conducted to assess mental performance, as well as the classic Stange's and Gench's breath holding tests for inspiration and expiration, respectively. The level of hemoglobin was also determined. In the vein of functional-metabolic continuum concept [9] an oral glucose tolerance test (OGTT) was also performed [8].

Lymphocyte phenotypes (markers CD3, CD4, CD8, CD16, CD19) were determined by the method of indirect immunofluorescence reaction of binding of monoclonal antibodies of IHC "Sorbent" with visualization under a fluorescence microscope. Theophylline-resistant and theophylline-sensitive T-lymphocyte subpopulations, serum levels of G, A, M immunoglobulins (radial immunodiffusion method) and circulating immune complexes (polyethylene glycol precipitation method) were also determined.

The state of the phagocytic link of immunity was judged by the activity of phagocytosis (phagocytic index), its intensity (microbial number) and completeness (killing index) against Staphylococcus aureus, with the calculation of bactericidal ability of neutrophils. Serum lysozyme activity was evaluated in the bacteriolysis test of Micrococcus lysodeikticus. To assess local immunity, lysozyme activity in mixed saliva was determined. Used the methodologies in the manuals $[14,18,19]$.

Patients received a standard balneotherapeutic complex, the basis of which was drinking 3 $\mathrm{ml} / \mathrm{kg}$ Naftussya water three times daily; mineral baths (concentration of Cl-SO $4-\mathrm{Na}_{4} \mathrm{Mg}$ salts 20 $30 \mathrm{~g} / \mathrm{L}$, t $36-37^{\circ} \mathrm{C}$, duration $8-10 \mathrm{~min}$ ) every other day, 8 procedures; ozokerite application to the lesion site $\left(\mathrm{t} 45^{\circ} \mathrm{C}\right.$, duration $\left.20-30 \mathrm{~min}\right)$ every other day, 8 procedures; dietary nutrition; therapeutic exercise. Adaptogenic properties of the complex and its components have been proven by previous studies of the Truskavetsian Scientific School of Balneology [10$13,16,17,20-27,29]$.

Results processed by methods of cluster and discriminant analyses, using the software package "Statistica 5.5".

\section{RESULTS AND DISCUSSION}

Preliminary analysis revealed multidirectional changes of the step-test, just as they are multidirectionally changed under the influence of adaptogens, in particular balneotherapy factors, parameters of various functional systems of the human body and animals $[3,4,11,16,17]$.

For further analysis, the contingent surveyed was retrospectively divided into three qualitatively distinct groups. The largest group $(53,7 \%)$ was the group of children with initially reduced or normal levels of PSI, in which it increased (Fig. 1), which is quite expected in line with the beneficial effect of balneotherapy on the body [16]. However, in 28,8\% of children PSI remained stable at different initial levels, and in 17,5\% even decreased, without falling below the lower limit of normal.

In the adult contingent of the Truskavets spa it was shown earlier [28] that due to complex balneotherapy, the index of tachycardia-hypertensive reaction to $1,5 \mathrm{~W} / \mathrm{kg}$ cycling load in $47,6 \%$ of patients increased by $16,6 \pm 2,4 \%$, in $26,2 \%$ of persons they did not go beyond $\pm 5 \%$, instead of the remaining $26,2 \%$ the value of this index decreased by an average of $10,0 \pm 1,0 \%$.

In an experiment on female rats [28], it was found that swimming time to fatigue in 6 
animals after 3 weeks of water Naftussya use increased from $13,0 \pm 1.4$ min to $52,3 \pm 5,9$ min, in 8 animals from $24,5 \pm 3,9$ min to $37,3 \pm 5,9 \mathrm{~min}$, instead of 4 rats with initial very high performance, adverse changes were observed, ie a reduction in swimming time from $61 \pm 7$ min to $39 \pm 3 \mathrm{~min}$. Thus, in the experimental model, a significant favorable actotropic effect was found in 33,3\% of individuals, moderately favorable in $44,4 \%$ and unfavorable in $22,2 \%$ of cases. At the same time, the causation of actotropic effects by Naftussya water has been proved.



Fig. 1. Individual levels of Popovych's step-test index (PSI) before (X-axis) and after (Y-axis) course of adaptogenic balneotherapy. Green lines indicate normal limits

Discriminant analysis [15] was subsequently applied to identify constellations of parameters that change are characteristic of each cluster. The program (forward stepwise) selected as characteristic changes in 2 parameters of autonomous nervous system, 2 functional, 4 metabolic and 3 immune parameters as well as blood trombocytes level. Of particular interest are a number of parameters that are not spent in the model (Tables 1 and 2). 
Table 1. Discriminant Function Analysis Summary for Accompaniments of Changes in Popovych's Step Test

Step 15, N of vars in model: 15; Grouping: 3 grps

Wilks' Lambda: 0,303; approx. $\mathrm{F}_{(30,1)}=3,4 ; \mathrm{p}<10^{-6}$

\begin{tabular}{|c|c|c|c|c|c|c|c|c|}
\hline \multirow[b]{2}{*}{$\begin{array}{l}\text { Changes in Variables } \\
\text { currently in the model }\end{array}$} & \multicolumn{3}{|c|}{ Changes in Popovych's Step Test } & \multicolumn{5}{|c|}{ Parameters of Wilks' Statistics } \\
\hline & $\begin{array}{l}\text { PST- } \\
-0,10 \pm 0,02 \\
(14)\end{array}$ & $\begin{array}{l}\mathrm{PST}_{0} \\
\mathbf{0 , 0 0 \pm 0 , 0 0} \\
(23)\end{array}$ & $\begin{array}{l}\text { PST }+ \\
+0,13 \pm 0,01 \\
(43)\end{array}$ & $\begin{array}{l}\text { Wilks } \\
\Lambda\end{array}$ & $\begin{array}{l}\text { Par- } \\
\text { tial } \\
\Lambda \\
\end{array}$ & $\begin{array}{l}\text { F- } \\
\text { remove }\end{array}$ & $\begin{array}{l}\text { p- } \\
\text { le- } \\
\text { vel }\end{array}$ & $\begin{array}{l}\text { Tole } \\
\text { ran- } \\
\text { cy } \\
\end{array}$ \\
\hline Leukocytes total, G/L & $-0,12 \pm 0,25$ & $-0,29 \pm 0,17$ & $+0,36 \pm 0,07$ & ,314 & ,966 & 1,1 & ,337 &, 800 \\
\hline Stange's Test, sec & $-2,6 \pm 3,6$ & $-2,3 \pm 2,5$ & $+5,9 \pm 1,8$ &, 350 & 867 & 4,9 & ,011 & ,799 \\
\hline Teslenko's Test, points & $0,2 \pm 0,6$ & $-0,4 \pm 0,3$ & $+1,0 \pm 0,3$ &, 410 &, 739 & 11 &, 000 &, 600 \\
\hline Trombocytes, G/L & $-4 \pm 5$ & $+11 \pm 6$ & $+20 \pm 5$ & ,320 & ,946 & 1,8 &, 173 &, 856 \\
\hline $\begin{array}{l}\text { Glucosa a 1h OGTT, } \\
\mathrm{mM} / \mathrm{L}\end{array}$ & $+0,15 \pm 0,31$ & $+0,38 \pm 0,16$ & $+0,63 \pm 0,10$ & ,314 & ,964 & 1,2 & ,315 & ,702 \\
\hline Glucosa basal, mM/L & $0,00 \pm 0,08$ & $+0,08 \pm 0,09$ & $+0,20 \pm 0,07$ & ,321 & ,943 & 1,9 & ,158 & ,192 \\
\hline CIC, units & $+18 \pm 11$ & $+14 \pm 6$ & $-6 \pm 6$ & ,356 & 851 & 5,5 & ,006 & ,481 \\
\hline AMo HRV, \% & $+2,5 \pm 2,5$ & $0,0 \pm 2,1$ & $-1,6 \pm 1,3$ &, 327 & ,926 & 2,5 &, 090 & ,696 \\
\hline Pan Lymphocytes, \% & $+4,5 \pm 2,2$ & $-1,3 \pm 1,4$ & $-0,9 \pm 1,3$ & ,325 & ,933 & 2,3 &, 113 &, 678 \\
\hline $\begin{array}{l}\text { Glycemia aft } 2 \mathrm{~h} \text { OGTT, } \\
\%\end{array}$ & $+7,4 \pm 4,4$ & $-1,6 \pm 4,7$ & $-1,7 \pm 3,5$ & ,314 & ,966 & 1,1 & ,333 & 077 \\
\hline Phagocytose Index, \% & $+18 \pm 3$ & $+8 \pm 2$ & $+10 \pm 1$ & ,358 &, 847 & 5,7 &, 005 & ,782 \\
\hline $\begin{array}{l}\text { Glucosa a } 2 \mathrm{~h} \text { OGTT, } \\
\mathrm{mM} / \mathrm{L}\end{array}$ & $+0,35 \pm 0,14$ & $-\mathbf{0 , 0 5} \pm 0,17$ & $+0,15 \pm 0,12$ & ,328 & ,923 & 2,6 & ,081 & 095 \\
\hline IgA Serum, g/L & $+0,15 \pm 0,28$ & $-0,15 \pm 0,18$ & $+0,24 \pm 0,11$ & ,316 & ,958 & 1,4 & ,262 & ,772 \\
\hline $\begin{array}{l}\text { Theoph Sensit T Lymph., } \\
\%\end{array}$ & $-3,6 \pm 1,2$ & $+1,6 \pm 1,2$ & $+1,0 \pm 1,1$ & 336 & ,903 & 3,4 & ,041 & 514 \\
\hline MxDMn HRV, sec & $0,00 \pm 0,05$ & $+0,04 \pm 0,02$ & $-0,01 \pm 0,02$ & ,354 &, 856 & 5,3 &, 007 & ,619 \\
\hline $\begin{array}{l}\text { Changes in Variables } \\
\text { currently not in the model }\end{array}$ & $\begin{array}{l}\text { PST- } \\
-0,10 \pm 0,02 \\
(14)\end{array}$ & $\begin{array}{l}\mathrm{PST}_{0} \\
\mathbf{0 , 0 0 \pm 0 , 0 0} \\
(23)\end{array}$ & $\begin{array}{l}\text { PST+ } \\
+0,13 \pm 0,01 \\
(43)\end{array}$ & $\begin{array}{l}\text { Wilks } \\
\Lambda\end{array}$ & $\begin{array}{l}\text { Par- } \\
\text { tial } \\
\Lambda\end{array}$ & $\begin{array}{l}\mathrm{F} \text { to } \\
\text { en-ter }\end{array}$ & $\begin{array}{l}\text { p- } \\
\text { le- } \\
\text { vel }\end{array}$ & $\begin{array}{l}\text { Tole } \\
\text { ran- } \\
\text { cy }\end{array}$ \\
\hline CD8 $^{+}$T Lymphocytes, \% & $-1,8 \pm 0,8$ & $+1,7 \pm 0,9$ & $+1,2 \pm 0,8$ & 297 & ,980 & ,63 &, 536 &, 051 \\
\hline $\begin{array}{l}\text { CD16 }{ }^{+} \text {NK Lymphocytes, } \\
\%\end{array}$ & $-2,2 \pm 2,2$ & $+2,6 \pm 1,0$ & $+2,3 \pm 1,0$ &, 302 & ,997 &, 09 & ,915 &, 319 \\
\hline $\begin{array}{l}\text { Theophyl Res T Lymph., } \\
\%\end{array}$ & $+7,5 \pm 2,9$ & $+3,3 \pm 1,8$ & $+3,4 \pm 1,8$ & ,297 & ,979 & ,65 & ,525 & 668 \\
\hline CD4 $^{+}$T Lymphocytes, \% & $+4,3 \pm 1,5$ & $+1,3 \pm 0,9$ & $+1,4 \pm 0,9$ & ,297 & ,979 & ,65 &, 525 & ,561 \\
\hline $\begin{array}{l}\text { Killing Index Neutroph, } \\
\%\end{array}$ & $+14 \pm 2$ & $+5 \pm 2$ & $+7 \pm 2$ & ,296 & ,976 & ,78 & ,464 &, 156 \\
\hline $\begin{array}{l}\text { Bactericidity Neutr, } 10^{9} \\
\text { B/L }\end{array}$ & $+7,43 \pm 1,47$ & $+4,31 \pm 0,77$ & $+4,87 \pm 0,70$ & ,301 & ,993 & 21 & 807 & ,328 \\
\hline Hemoglobin, g/L & $+0,45 \pm 0,57$ & $-0,11 \pm 0,34$ & $+0,84 \pm 0,26$ & ,302 & ,995 & ,14 &, 867 & ,728 \\
\hline $\begin{array}{l}\text { Erythroc Sedim Rate, } \\
\mathrm{mm} / \mathrm{h}\end{array}$ & $0,0 \pm 0,5$ & $-1,6 \pm 0,4$ & $-0,2 \pm 0,3$ & ,299 & ,985 & ,46 & ,632 &, 850 \\
\hline $\begin{array}{l}\text { Anfimov's Test, error } / 2 \\
\text { min }\end{array}$ & $-1,2 \pm 0,9$ & $-2,3 \pm 0,5$ & $-0,9 \pm 0,3$ & 297 & ,981 & ,62 & 543 & ,732 \\
\hline Hench's Test, sec & $+1,6 \pm 4,4$ & $-0,1 \pm 2,8$ & $+5,3 \pm 1,3$ & ,295 & ,974 & ,83 & ,441 & ,596 \\
\hline $\begin{array}{l}\text { Segmented Neutrophils, } \\
\%\end{array}$ & $-0,9 \pm 2,5$ & $+3,4 \pm 1,5$ & $-0,9 \pm 1,3$ & 298 & ,983 & 55 & 582 & 824 \\
\hline CD19 $^{+}$B Lymphocytes, \% & $+0,4 \pm 0,8$ & $+1,6 \pm 0,6$ & $+0,6 \pm 0,4$ & 299 & ,985 & ,47 & ,625 & ,663 \\
\hline
\end{tabular}


Table 2. Summary of Stepwise Analysis for Accompaniments of Changes in Popovych's Step Test. The variables are ranked by criterion Lambda

\begin{tabular}{|l|l|l|l|l|l|}
\hline $\begin{array}{l}\text { Changes in Variables currently in } \\
\text { the model }\end{array}$ & $\begin{array}{l}\text { F to } \\
\text { enter }\end{array}$ & $\begin{array}{l}\text { p- } \\
\text { level }\end{array}$ & $\boldsymbol{\Lambda}$ & $\begin{array}{l}\text { F- } \\
\text { value }\end{array}$ & $\begin{array}{l}\text { p- } \\
\text { level }\end{array}$ \\
\hline Leukocytes total, G/L & 6,1 &, 004 &, 864 & 6,1 &, 004 \\
\hline Phagocytose Index, \% & 4,9 &, 010 &, 765 & 5,4 & $10^{-3}$ \\
\hline Stange's Test, sec & 3,5 &, 037 &, 701 & 4,9 & $10^{-3}$ \\
\hline Teslenko's Test, points & 4,9 &, 010 &, 619 & 5,0 & $10^{-4}$ \\
\hline Glucosa basal, mM/L & 3,1 &, 050 &, 570 & 4,7 & $10^{-5}$ \\
\hline CIC, units & 2,6 &, 084 &, 532 & 4,5 & $10^{-5}$ \\
\hline Theophilline Sensitive T Lymph., \% & 3,0 &, 057 &, 491 & 4,3 & $10^{-5}$ \\
\hline MxDMn HRV, sec & 3,3 &, 042 &, 448 & 4,3 & $10^{-6}$ \\
\hline Glucosa after 2h OGTT, mM/L & 2,9 &, 064 &, 414 & 4,3 & $10^{-6}$ \\
\hline AMo HRV, \% & 2,2 &, 122 &, 389 & 4,1 & $10^{-6}$ \\
\hline Pan Lymphocytes, \% & 3,3 &, 044 &, 354 & 4,1 & $10^{-6}$ \\
\hline Trombocytes, G/L & 1,5 &, 240 &, 339 & 3,9 & $10^{-6}$ \\
\hline IgA Serum, g/L & 1,6 &, 218 &, 324 & 3,8 & $10^{-6}$ \\
\hline Glucosa after 1h OGTT, mM/L & 1,0 &, 365 &, 314 & 3,6 & $10^{-6}$ \\
\hline Glycemia after 2h OGTT, \% & 1,1 &, 333 &, 303 & 3,4 & $10^{-6}$ \\
\hline
\end{tabular}

Next, the 15-dimensional space of discriminant variables transforms into 2-dimensional space of canonical roots. The canonical correlation coefficient is for Root 10,738 (Wilks' $\Lambda=0,303$; $\chi^{2}{ }_{(30)}=84 ; \mathrm{p}<10^{-6}$ ) and for Root 20,578 (Wilks' $\Lambda=0,666 ; \chi^{2}(14)=28 ; \mathrm{p}=0,012$ ). The major root contains $70,5 \%$ of discriminative opportunities and the minor is $29,5 \%$.

Table 3 presents standardized (normalized) and raw (actual) coefficients for discriminant variables. The calculation of the discriminant root values for each person as the sum of the products of raw coefficients to the individual values of discriminant variables together with the constant enables the visualization of each patient in the information space of the roots (Fig. 2). 
Table 3. Standardized and Raw Coefficients and Constants for Canonical Variables

\begin{tabular}{|c|c|c|c|c|}
\hline Coefficients & \multicolumn{2}{|c|}{ Standardized } & \multicolumn{2}{|c|}{ Raw } \\
\hline $\begin{array}{l}\text { Changes in Variables currently in } \\
\text { the model }\end{array}$ & $\begin{array}{l}\text { Root } \\
1\end{array}$ & $\begin{array}{l}\text { Root } \\
2\end{array}$ & $\begin{array}{l}\text { Root } \\
1\end{array}$ & $\begin{array}{l}\text { Root } \\
2\end{array}$ \\
\hline Leukocytes total, G/L & 206 & 240 & ,335 & ,391 \\
\hline Phagocytose Index, \% &,- 335 & ,633 &,- 035 &, 066 \\
\hline Stange's Test, sec & ,551 & ,070 &, 045 &, 006 \\
\hline Teslenko's Test, points & ,881 & ,186 & ,448 &, 095 \\
\hline Glucosa basal, mM/L & ,518 &,- 669 & 1,215 & $-1,569$ \\
\hline CIC, units &,- 717 &,- 295 &,- 020 &,- 008 \\
\hline Theophilline Sensitive T Lymph., \% &,- 459 &,- 468 &,- 074 &,- 075 \\
\hline MxDMn HRV, sec &,- 497 &,- 541 & $-3,572$ & $-3,888$ \\
\hline Glucosa after $2 \mathrm{~h}$ OGTT, mM/L & ,103 & 1,551 & ,133 & 2,001 \\
\hline AMo HRV, \% &,- 429 & ,128 &,- 047 & ,014 \\
\hline Pan Lymphocytes, \% &,- 344 & ,320 &,- 043 & ,040 \\
\hline Trombocytes, G/L & ,285 &,- 239 & ,009 &,- 008 \\
\hline IgA Serum, g/L & ,306 &,- 095 & ,372 &,- 115 \\
\hline Glucosa after $1 \mathrm{~h}$ OGTT, mM/L &,- 092 &,- 374 &,- 116 &,- 473 \\
\hline \multirow[t]{4}{*}{ Glycemia after 2h OGTT, \% } & ,001 & $-1,156$ & ,000 &,- 053 \\
\hline & \multicolumn{2}{|r|}{ Constants } &,- 136 &,- 453 \\
\hline & \multicolumn{2}{|c|}{ Eigenvalues } & 1,198 & ,501 \\
\hline & \multicolumn{2}{|c|}{ Cum. Properties } & ,705 & 1,000 \\
\hline
\end{tabular}

Table 4 shows the correlation coefficients of PST changes (discriminant variables) with canonical discriminant roots and the cluster centroids of both roots.

Table 4. Correlations Variables-Canonical Roots and Roots Means of changes in Variables for Clusters

\begin{tabular}{|c|c|c|}
\hline $\begin{array}{l}\text { Changes in Variables currently in } \\
\text { the model }\end{array}$ & $\begin{array}{r}\text { Cor } \\
\text { Varia } \\
\end{array}$ & $\begin{array}{l}\text { lations } \\
\text { es-Roots }\end{array}$ \\
\hline Root $1(\mathbf{7 0 , 5 \% )}$ & R 1 & $\mathbf{R} 2$ \\
\hline Leukocytes total, G/L & ,357 & 105 \\
\hline Stange's Test, sec & ,316 &, 002 \\
\hline Teslenko's Test, points & 277 & ,146 \\
\hline Trombocytes, G/L & 218 &,- 221 \\
\hline Glucosa after1h OGTT, mM/L & ,199 &,- 134 \\
\hline Glucosa basal, mM/L & ,163 &,- 079 \\
\hline CIC, units &,- 262 &, 042 \\
\hline AMo HRV, \% &,- 134 &, 129 \\
\hline Pan Lymphocytes, \% &,- 108 & ,339 \\
\hline Glycemia after $2 \mathrm{~h}$ OGTT, $\%$ &,- 077 &, 193 \\
\hline Root $2(29,5 \%)$ & R 1 & R 2 \\
\hline Phagocytose Index, \% &,- 110 &, 480 \\
\hline Glucosa after $2 \mathrm{~h}$ OGTT, $\mathrm{mM} / \mathrm{L}$ &, 020 & ,245 \\
\hline IgA Serum, g/L & 154 & ,175 \\
\hline Theophiline Sensitive T Lymph., \% & ,093 &,- 336 \\
\hline MxDMn HRV, sec &,- 109 &,- 142 \\
\hline
\end{tabular}

The above allows us to comment on Fig. 2 as follows. The localization of points representing children with PST growth in the right area of the axis of the first root reflects the 
fact that it is accompanied by an increase in variables that correlate positively with the radical (Table 4), namely (Table 1): respiration delay time, improvement orthostatic test, increased blood levels of common leukocytes and platelets, basal glycemia, and one hour after oral glucose loading. On the other hand, the increase in PST is accompanied by a decrease in sympathetic tone and blood content of circulating immune complexes and a tendency to decrease the late hyperglycemic response to the loading of glucose and the proportion of pan-lymphocytes associated with the root inverse. We consider the described changes physiologically favorable.

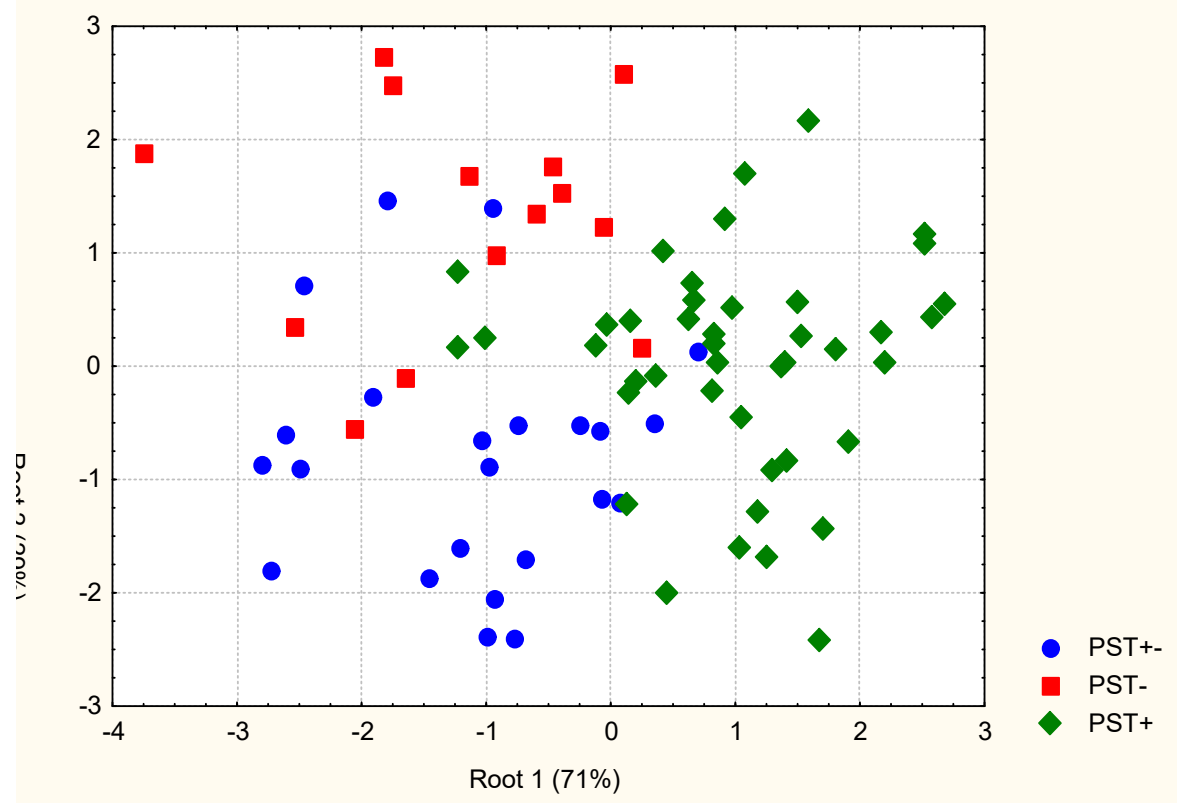

Fig. 2. Scatterplot of individual values of the first and second roots in which condensed information about of the changes in parameters of the members of the three clusters

On the opposite side are localized projections on the axis of points, which represent children with stable PST and its negative dynamics, which are mixed, reflecting approximately the same decrease/increase in the above variables.

These two groups of children are separated along the axis of the second radical. The upper position of points of children with negative PST changes reflects more pronounced, than in the neutral group, an increase in phagocytosis activity and a positive, as opposed to negative, dynamics of IgA levels and a late hyperglycemic reaction to glucose loading, on the one hand, and a decrease in the proportion of theophylline sensitive T-Lymphocytes and no increase in vagus tone, while in the other group both variables increase - on the other hand.

Taking into account variables that are not included in the model (Table 1), we see that the negative dynamics of PST is accompanied by a decrease in the proportion of blood T-killers and natural killers in combination with an increase in T-helpers and bactericidal neutrophils, ie physiological assessment is ambiguous.

Despite the individual ectopies, on the plane of the two discriminative roots, the members of the three groups are delimited statistically, which is documented by the calculation of Mahalanobis distances (Table 5). 
Table 5. Squared Mahalanobis Distances between Clusters, F-values and p levels

\begin{tabular}{|l|l|l|l|}
\hline Clusters & PST $_{\mathbf{0}}$ & PST- & PST+ \\
\hline PST $_{\mathbf{0}}$ & 0,00 & $\mathbf{4 , 6 1}$ & $\mathbf{5 , 4 0}$ \\
\hline PST- & $\begin{array}{l}\mathbf{2 , 0 6} \\
\mathbf{0 , 0 2 5}\end{array}$ & 0,00 & $\mathbf{6 , 7 2}$ \\
\hline PST+ & $\begin{array}{l}\mathbf{4 , 2 6} \\
<10^{-4}\end{array}$ & $\begin{array}{l}\mathbf{3 , 6 4} \\
<10^{-3}\end{array}$ & 0,00 \\
\hline
\end{tabular}

The same discriminant parameters can be used to identify the belonging of one or another person to one or another cluster. This purpose of discriminant analysis is realized with the help of classifying functions (Table 6).

Table 6. Coefficients and Constants for Classification Functions of Clusters

\begin{tabular}{|l|l|l|l|}
\hline \multirow{2}{*}{$\begin{array}{l}\text { Changes in Variables currently in the } \\
\text { model }\end{array}$} & PST $_{\mathbf{0}}$ & PST- & PST+ \\
\cline { 2 - 4 } & $\mathrm{p}=, 288$ & $\mathrm{p}=, 175$ & $\mathrm{p}=, 537$ \\
\hline Leukocytes total, G/L &,- 737 &, 061 &, 298 \\
\hline Phagocytose Index, \% &, 116 &, 257 &, 096 \\
\hline Stange's Test, sec &,- 047 &,- 038 &, 053 \\
\hline Teslenko's Test, points &,- 547 &,- 381 &, 484 \\
\hline Glucosa basal, mM/L &, 252 & $-3,141$ & 1,535 \\
\hline CIC, units &, 034 &, 018 &,- 015 \\
\hline Theophilline Sensitive T Lymph., \% &, 158 &, 005 &,- 062 \\
\hline MxDMn HRV, sec & 7,241 &,- 682 & $-3,569$ \\
\hline Glucosa after 2h OGTT, mM/L & $-1,479$ & 2,724 &, 460 \\
\hline AMo HRV, \% &, 053 &, 086 &,- 036 \\
\hline Pan Lymphocytes, \% &, 038 &, 126 &,- 020 \\
\hline Trombocytes, G/L &, 012 &,- 005 &, 025 \\
\hline IgA Serum, g/L &,- 343 &,- 613 &, 352 \\
\hline Glucosa after 1h OGTT, mM/L & 1,487 &, 499 &, 849 \\
\hline Glycemia after 2h OGTT, \% &, 034 &,- 076 &,- 009 \\
\hline Constants & $-2,813$ & $-4,842$ & $-2,378$ \\
\hline
\end{tabular}

The correct classification of the positive actotropic effect is $93,0 \%$; neutral $65,2 \%$; negative $64,3 \%$, and total correctness is $80,0 \%$ (Table 7 ).

Table 7. Classification Matrix for Clusters

Rows: Observed classifications; Columns: Predicted classifications

\begin{tabular}{|l|l|l|l|l|}
\hline & Percent & PST + & PST $_{\mathbf{0}}$ & PST- \\
\hline Clusters & Correct & $\mathrm{p}=, 538$ & $\mathrm{p}=, 287$ & $\mathrm{p}=, 175$ \\
\hline PST + & 93,0 & $\mathbf{4 0}$ & $\mathbf{2}$ & $\mathbf{1}$ \\
\hline PST $_{\mathbf{0}}$ & 65,2 & $\mathbf{5}$ & $\mathbf{1 5}$ & $\mathbf{3}$ \\
\hline PST- & 64,3 & $\mathbf{2}$ & $\mathbf{3}$ & $\mathbf{9}$ \\
\hline Total & 80,0 & 47 & 20 & 13 \\
\hline
\end{tabular}

To compare accuracy, we recall that in adult patients were selected for inclusion in model 10 variables from 72 counts (in order of decreasing F-value): tachycardia-hypertensive load index, Klimov atherogenic factor, cholesterol content VLD LP, sodium content erythrocytes, activity of $\mathrm{Na}, \mathrm{K}-\mathrm{ATP}$ ase erythrocyte shadows, level of diastolic and systolic blood pressure; the plasma potassium and urates content, as well as the Ruzhylo-Popovych's contractile activity index of 
myocardium. The correct classification of the positive actotropic effect is $81,0 \%$; neutral $60,0 \%$; negative $72,7 \%$, and total correctness is $75,6 \%$ [28].

In the next article, the possibility of predicting the diversity of actotropic effects of adaptogenic balneotherapy will be considered.

\section{ACKNOWLEDGMENT}

We express sincere gratitude to colleagues of clinical sanatorium "Dzherelo" for help in conducting this investigation.

\section{ACCORDANCE TO ETHICS STANDARDS}

Tests in patients are conducted in accordance with positions of Helsinki Declaration 1975, revised and complemented in 2002, and directive of National Committee on ethics of scientific researches. During realization of tests from all parent of participants the informed consent is got and used all measures for providing of anonymity of participants.

For all authors any conflict of interests is absent.

\section{REFERENCES}

1. Amosov MV, Bendet YaA. Physical activity and heart [in Russian]. Kyiv. Zdorovya; 1989: 215 p.

2. Baevskiy RM, Ivanov GG. Heart Rate Variability: theoretical aspects and possibilities of clinical application [in Russian]. Ultrazvukovaya i funktsionalnaya diagnostika. 2001; 3: 106-127.

3. Balanovs'kyi VP, Popovych IL, Karpynets' SV. About ambivalence-equilibratory character of influence of curative water Naftussya on organism of human [in Ukrainian]. Dopovidi ANU. Mat., pryr., tekhn. Nauky. 1993; 3: 154-158.

4. Chebanenko OI, Chebanenko LO, Popovych IL. Variety Balneoeffects of Factors Spa Truskavets' and their Forecast [in Ukrainian]. Kyiv: UNESCO-SOCIO; 2012: 496 p.

5. Douglas SD, Quie PG. Investigation of Phagocytes in Disease. Churchil; 1981: $110 \mathrm{p}$.

6. Druz' VA. Sports Training and Body [in Russian]. Kyiv. Zdorovya; 1980: 128 p.

7. Dushanin SA, Pyrohova OYa, Ivashchenko LYa. Wellness Run [in Ukrainian]. Kyiv. Zdorovya; 1982: $128 \mathrm{p}$.

8. Goryachkovskiy AM. Clinical Biochemistry [in Russian]. Odesa. Astroprint; 1998: 608 p.

9. Gozhenko AI. Functional-metabolic continuum [in Russian]. J NAMS of Ukraine. 2016; 22(1): 38.

10. Gozhenko AI, Sydoruk NO, Babelyuk VYe, Dubkowa GI, Flyunt VR, Hubyts'kyi VYo, Zukow W, Barylyak LG, Popovych IL. Modulating effects of bioactive water Naftussya from layers Truskavets' and Pomyarky on some metabolic and biophysic parameters at humans with dysfunction of neuro-endocrine-immune complex. Journal of Education, Health and Sport. 2016; 6(12): 826-842.

11. Gozhenko AI, Zukow W, Polovynko IS, Zajats LM, Yanchij RI, Portnichenko VI, Popovych IL. Individual Immune Responses to Chronic Stress and their Neuro-Endocrine Accompaniment. RSW. UMK. Radom. Torun; 2019: 200 p.

12. Ivassivka SV, Bilas VR, Popovych AI. Stresslimiting effects of ozokerite on neuro-endocrineimmune complex at rats. In: International Scientific Congress and 61-st Session of the General Assembly of the World Federation of Hydrotherapy Climatotherapy (FEMTEC). Congress materials (China, November 26-28, 2008): 216-217.

13. Ivassivka SV, Bilas VR, Popovych AI. Influence applications of ozokerite on phone of chronic stress on parameters of neuro-endocrine-immune complex and hydro-electrolyte exchange at rats. Communication 1: Stresslimiting, sanogene and neutral effects [in Ukrainian]. Medical Hydrology 
and Rehabilitation. 2008; 6(4): 65-72.

14. Khaitov RM, Pinegin BV, Istamov KhI. Ecological Immunology [in Russian]. Moskwa: VNIRO; 1995: $219 \mathrm{p}$.

15. Klecka WR. Discriminant Analysis [trans. from English in Russian] (Seventh Printing, 1986). In: Factor, Discriminant and Cluster Analysis. Moskva. Finansy i Statistika; 1989: 78-138.

16. Kostyuk PG, Popovych IL, Ivassivka SV (editors). Chornobyl', Adaptive and Defensive Systems, Rehabilitation [in Ukrainian]. Kyiv. Computerpress; 2006: 348 p.

17. Kozyavkina OV, Kozyavkina NV, Gozhenko OA, Gozhenko AI, Barylyak LG, Popovych IL. Bioactive Water Naftussya and Neuroendocrine-Immune Complex [in Ukrainian]. Kyiv. UNESCO-SOCIO; 2015: $349 \mathrm{p}$.

18. Lapovets' LY, Lutsyk BD. Handbook of Laboratory Immunology [in Ukrainian]. Lviv; 2002: 173 p.

19. Perederiy VG, Zemskov AM, Bychkova NG, Zemskov VM. Immune status, principles of its evaluation and correction of immune disorders [in Russian]. Kyiv. Zdorovya; 1995: 211 p.

20. Popovych AI. Features of the immunotropic effects of partial components of the balneotherapeutic complex of spa Truskavets'. Journal of Education, Health and Sport. 2018; 8(12): 919-935.

21. Popovych AI. Features of the neurotropic effects of partial components of the balneotherapeutic complex of spa Truskavets'. Journal of Education, Health and Sport. 2019; 9(1): 396-409.

22. Popovych IL. Stresslimiting Adaptogene Mechanism of Biological and Curative Activity of Water Naftussya [in Ukrainian]. Kyiv. Computerpress; 2011: 300 p.

23. Popovych IL, Barylyak LG. Influence of course using of bioactive water Naftussya on stress level at women with endocrine and gynecological pathology [in Ukrainian]. Medical Hydrology and Rehabilitation. 2009; 7(3): 100-118.

24. Popovych IL, Flyunt IS, Alyeksyeyev OI, Barylyak LG, Bilas VR. Sanogenetic Bases of Rehabilitation on Spa Truskavets' Urological Patients from Chornobylian Contingent [in Ukrainian]. Kyiv. Computerpress; 2003: 192 p.

25. Popovych IL, Gumega MD, Verba IE, Popovych AI, Korolyshyn TA, Tkachuk SP, Ostapenko VM, Zukow W. Comparative investigation effects on nervous and immune systems of bioactive water Naftussya spa Truskavets' and stable water solution of Boryslav's ozokerite. Journal of Education, Health and Sport. 2016; 6(4): 364-374.

26. Popovych IL, Ruzhylo SV, Ivassivka SV, Aksentiychuk BI (editors). Balneocardioangiology [in Ukrainian]. Kyiv. Computerpress; 2005: 229 p.

27. Popovych IL, Vis'tak (Markevych) HI, Humega MD, Ruzhylo SV. Vegetotropic Effects of Bioactive Water Naftussya and their Neuroendocrine-Immune, Metabolic and Hemodynamic Accompaniments [in Ukrainian]. Kyiv. UNESCO-SOCIO; 2014: 162 p.

28. Ruzhylo SV, Tserkovnyuk AV, Ророрvych IL. Актотропні ефекти бальнеотерапевтичного комплексу курорту Трускавець. Actotropic Effects of Balneotherapeutic Complex of Truskavets spa [in Ukrainian]. Kyiv. Computerpress; 2003: 131 p.

29. Sydoruk NO, Zukow W. Differences between the effects of water Naftussya from fields of Truskavets' and Pomyarky on the parameters of the EEG, HRV, immunity and metabolism. Journal of Education, Health and Sport. 2019; 9(1): 287-293. 